\title{
Total forearm blood flow as an indicator of skeletal muscle blood flow: effect of subcutaneous adipose tissue blood flow
}

Citation for published version (APA):

Blaak, E. E., van Baak, M. A., Kemerink, G. J., Pakbiers, M. T., Heidendal, G. A. K., \& Saris, W. H. M. (1994). Total forearm blood flow as an indicator of skeletal muscle blood flow: effect of subcutaneous adipose tissue blood flow. Clinical Science, 87(5), 559-566. https://doi.org/10.1042/cs0870559

Document status and date:

Published: 01/01/1994

DOI:

$10.1042 / \operatorname{cs} 0870559$

Document Version:

Publisher's PDF, also known as Version of record

\section{Please check the document version of this publication:}

- A submitted manuscript is the version of the article upon submission and before peer-review. There can be important differences between the submitted version and the official published version of record. People interested in the research are advised to contact the author for the final version of the publication, or visit the DOI to the publisher's website.

- The final author version and the galley proof are versions of the publication after peer review.

- The final published version features the final layout of the paper including the volume, issue and page numbers.

Link to publication

\footnotetext{
General rights rights.

- You may freely distribute the URL identifying the publication in the public portal. please follow below link for the End User Agreement:

www.umlib.nl/taverne-license

Take down policy

If you believe that this document breaches copyright please contact us at:

repository@maastrichtuniversity.nl

providing details and we will investigate your claim.
}

Copyright and moral rights for the publications made accessible in the public portal are retained by the authors and/or other copyright owners and it is a condition of accessing publications that users recognise and abide by the legal requirements associated with these

- Users may download and print one copy of any publication from the public portal for the purpose of private study or research.

- You may not further distribute the material or use it for any profit-making activity or commercial gain

If the publication is distributed under the terms of Article $25 \mathrm{fa}$ of the Dutch Copyright Act, indicated by the "Taverne" license above, 


\title{
Total forearm blood flow as an indicator of skeletal muscle blood flow: effect of subcutaneous adipose tissue blood flow
}

\author{
E. E. BLAAK, M. A. van BAAK, G. J. KEMERINK*†, M. T. W. PAKBIERS*, G. A. K. HEIDENDAL* \\ and W. H. M. SARIS \\ Department of Human Biology, University of Limburg, Maastricht, The Netherlands, and \\ *Department of Nuclear Medicine and †Department of Radiology, University Hospital \\ Maastricht, Maastricht, The Netherlands
}

(Received 2 March/30 june 1994; accepted II July 1994)

1. In studying forearm skeletal muscle substrate exchange, an often applied method for estimating skeletal muscle blood flow is strain gauge plethysmography. A disadvantage of this method is that it only measures total blood flow through a segment of forearm and not the flow through the individual parts such as skin, adipose tissue and muscle.

2. In the present study the contribution of forearm subcutaneous adipose tissue blood flow to total forearm blood flow was evaluated in lean (\% body fat $17.0 \pm 2.2)$ and obese males ( $\%$ body fat $30.9 \pm 1.6)$ during rest and during infusion of the non-selective $\beta$ agonist isoprenaline. Measurements were obtained of body composition (hydrostatic weighing), forearm composition (magnetic resonance imaging) and of total forearm (venous occlusion plethysmography), skin (skin blood flow, laser Doppler), and subcutaneous adipose tissue blood flow $\left({ }^{133} \mathrm{Xe}\right.$ washout technique).

3. The absolute forearm area and the relative amount of fat $(\%$ of forearm area) were significantly higher in obese as compared to lean subjects, whereas the relative amounts of muscle and skin were similar.

4. During rest, the percentage contribution of adipose tissue blood flow to total forearm blood flow was significantly higher in lean compared with obese subjects ( 19 vs $12 \%, P<0.05)$, whereas there were no differences in percentage contribution between both groups during isoprenaline infusion (10 vs 13\%). Furthermore, the contribution of adipose tissue blood flow to total forearm blood flow was significantly lower during isoprenaline infusion than during rest in lean subjects $(P<0.05)$, whereas in the obese this value was similar during rest and during isoprenaline infusion.

5. In conclusion, although the overall contribution of adipose tissue blood flow to total forearm blood flow seems to be relatively small, the significance of this contribution may vary with degree of adiposity. Calculations on the contribution of adipose tissue blood flow and SBF to total forearm blood flow indicate that the contribution of non-muscular flow to total forearm blood flow may be of considerable importance and may amount in lean subjects to $35-50 \%$ of total forearm blood flow in the resting state.

\section{INTRODUCTION}

To an increasing extent attention is paid to skeletal muscle metabolism at rest and during other conditions e.g. exercise, trauma and malnutrition. This interest is related to the relatively high muscle mass ( $\pm 40 \%$ of total body mass) and the significance of skeletal muscle in whole body energy expenditure and its role as protein and carbohydrate store. The substrate exchange of skeletal muscle has been thoroughly investigated by measuring the arterio-venous concentration differences of substrates across the forearm in combination with a measurement of blood flow. An often applied method to obtain an indication of skeletal muscle blood flow is strain gauge venous occlusion plethysmography [1]. The drawback is this method is that it only measures total blood flow through a segment of the forearm and not the flow through the individual parts such as the skin, adipose tissue and skeletal muscle. Although skeletal muscle may account for $60 \%$ or more of the forearm tissues [2], a significant contribution of the other forearm tissues to total forearm blood flow cannot be excluded. In the past, most research has been focussed on a separation of forearm muscle and skin blood by a combination of plethysmography and adrenalin iontophoresis [3-5]. In several more recent forearm studies $[6,7]$ subcutaneous adipose tissue blood flow has also been measured by means of the ${ }^{133} \mathrm{Xe}$ washout technique. However, since exact data on forearm composition are lacking in these studies, a good indication of the contribution

Key words: adipose tissue, blood flow, plethysmography, skeletai muscle, xenon.

Abbreviations: ATBF, adipose tissue blood flow; BMi, body mass index; ISO, isoprenaline; MRI, magnetic resonance imaging; SBF, skin blood flow; TBF, total forearm blood flow. Correspondence: Dr E. E. Blaak, Department of Human Biology, University of Limburg, P.O. Box 616,6200 MD Maastricht, The Netherlands. 
Table I. Body and forearm composition of lean compared with obese subjects. Values are means $\pm \operatorname{SEM}$. Lean, $n=8$, obese, $n=8$; Unpaired t-test: $*=P<0.05, t=P<0.01, \neq=P<0.001$. Abbreviation: BMI, Body mass index; \%, percentage of total forearm area.

\begin{tabular}{lcc}
\hline & Lean & \multicolumn{1}{l}{ Obese } \\
\hline Age (years) & $25.0 \pm 1.6$ & $31.8 \pm 1.6^{*}$ \\
BMl $\left(\mathrm{kg} / \mathrm{m}^{2}\right)$ & $23.2 \pm 1.4$ & $31.7 \pm 1.6 \$$ \\
\% Body fat & $17.0 \pm 2.2$ & $30.9 \pm 1.9 \$$ \\
Forearm composition & & \\
Total forearm area $\left(\mathrm{mm}^{2}\right)$ & $5576 \pm 144$ & $7817 \pm 290 \ddagger$ \\
\% subcutaneous fat & $13.9 \pm 1.0$ & $20.9 \pm 1.1 \dagger$ \\
$\%$ muscle tissue & $62.8 \pm 1.1$ & $61.0 \pm 1.0$ \\
\% skin & $9.3 \pm 0.1$ & $7.9 \pm 0.1 \ddagger$ \\
$\%$ bone & $7.9 \pm 0.2$ & $4.5 \pm 0.3 \ddagger$ \\
\% tendon & $6.1 \pm 0.2$ & $5.7 \pm 0.1^{*}$ \\
\hline
\end{tabular}

of subcutaneous adipose tissue flow to total blood flow cannot be obtained. In addition, subcutaneous adipose tissue blood flow has been reported to decrease with increasing degree of obesity [8], which implies that the importance of adipose tissue blood flow for the magnitude of total forearm blood flow may vary between subjects.

In the present study, the contribution of subcutaneous adipose tissue blood flow to total forearm blood flow was evaluated in lean and obese subjects. Measurements were performed on total forearm (venous occlusion plethysmography), skin (laser Doppler), and subcutaneous adipose tissue blood flow ( ${ }^{133} \mathrm{Xe}$ washout) during rest and during infusion of the non-selective $\beta$-adrenoceptor agonist isoprenaline (ISO), which is a potent stimulator of muscle blood flow [9]. The amount of forearm subcutaneous adipose tissue and muscle tissue were determined using magnetic resonance imaging (MRI).

\section{SUBJECTS AND METHODS}

In this study eight lean and eight obese men participated. Subject's characteristics are indicated in Table 1. All subjects were in good health, as assessed by a medical questionnaire and by physical examination. The study protocol was approved by the Ethics committee of the University of Limburg and all volunteers were asked for written consent. Measurements of body composition and forearm composition were made with hydrostatic weighing and MRI, respectively. After an overnight fast, blood flow measurements were performed on the total forearm, forearm skin and forearm subcutaneous adipose tissue during rest and during intravenous infusion of the non-selective $\beta$-agonist isoprenaline (ISO). Room temperature was controlled between 21 and $23^{\circ} \mathrm{C}$.

\section{Body composition}

Body density was determined with hydrostatic weighing with simultaneous lung volume measure-

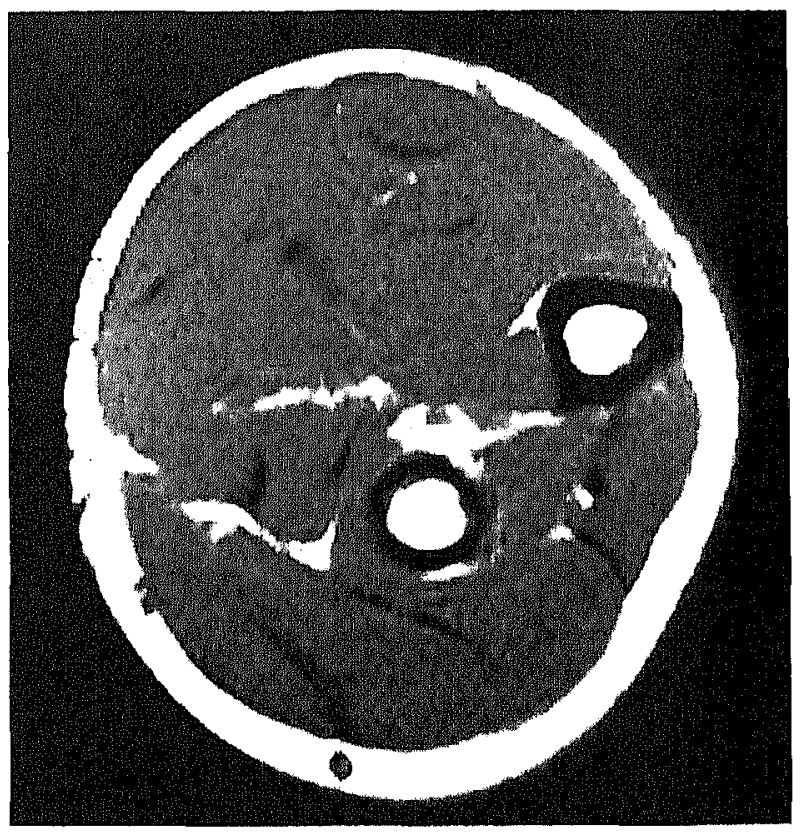

Fig. I. A magnetic resonance image showing a cross-section of the forearm at the site of the greatest circumference (spin echo, repetition time $200 \mathrm{~ms}$, echo time $20 \mathrm{~ms}$ ). The inner grey area represents muscle, whereas the surrounding white area represents subcutaneous fat tissue. The two inner circular structures represent bones: the inner white areas represent bone marrow and the surrounding black areas represent bone cortex.

ment (Volugraph 2000, Mijnhardt, The Netherlands). Body composition was calculated according to the formula of Siri [10].

\section{Forearm composition}

The amounts of subcutaneous fat, bone and muscle were determined by a cross-sectional analysis at the site of the greatest forearm circumference with MRI (Gyroscan T5, Philips Medical Systems, The Netherlands). T1-weighted images were obtained by means of a spin echo sequence at the greatest circumference of the forearm (repetition time $200 \mathrm{~ms}$, echo time $20 \mathrm{~ms}$, three slices of $10 \mathrm{~mm}$ thickness, $1 \mathrm{~mm}$ between slices). A surface coil was used during the imaging process. The acquisition time for imaging three slices of one forearm was about $40 \mathrm{~s}$. The above described imaging conditions were selected to emphasize differentiation of fat to non-fat tissues. In the images produced, fat was depicted as a very high intensity signal tissue, clearly separated from muscle and bone (Fig. 1). Cortical bone virtually gives no signal, resulting in good contrast with soft tissue. The images were segmented in areas with fat, non fatty soft tissue and areas within the cortical bone boundaries. We used a threshold based contouring algorithm implemented on a Philips Gyroview work station. In some cases user interaction was required, mainly as 
a consequence of a less than perfect correction for signal fall-off associated with the application of a surface coil. Visually, the boundary between fat and other soft tissue could usually be well distinguished in these instances and correction by hand was easy. For each subject the mean forearm composition of three slices was taken (1 $\mathrm{mm}$ in between). To obtain an indication of the variability in the method of analysis the tissue areas were calculated five times on a single scan. The coefficient of variation for repeated measurements was for subcutaneous adipose tissue, bone and muscle less than three per cent, In the MRI images neither the amount of forearm skin nor a distinction of the amount of muscle from tendonous structure could be determined. Therefore, skin thickness was assumed to be $2 \mathrm{~mm}$ in both lean and obese subjects. In addition, the relationship between the area of tendon and muscle was considered to be as assessed in the study of Cooper [2]. Under the heading of muscle is also grouped intramuscular fat and under the heading of both muscle and adipose tissue are also grouped nerves and blood vessels within these tissues.

\section{Blood flow}

The blood flow through the total forearm, forearm skin, and forearm subcutaneous adipose tissue was investigated at the end of a $30 \mathrm{~min}$ period of supine rest. After this control period, an intravenous infusion of isoprenaline (ISO) was started for 30 min. The blood flow measurements were repeated at the end of this infusion period. For cach subject, a standardized dose of ISO corresponding to a plasma ISO concentration of $165 \mathrm{pg} / \mathrm{ml}$ was infused. This dose was extrapolated from data of a pre-study where plasma ISO concentrations were determined during infusion of increasing standardized doses, as described elsewhere [11]. The mean infusion dose of ISO was $20 \mathrm{ng} \mathrm{kgFim}$ min $^{-1}$ in both lean and obese subjects.

Total forearm blood flow. Total forearm blood flow was measured by venous occlusion plethysmography [1] with a mercury strain gauge (Periflow 0669; Janssen Scientific Instruments, Belgium). The strain gauge was placed around the forearm at the site of the greatest circumference. Prior to measuring blood flow, the hand circulation was occluded by inflating a pediatric sphygmanometer cuff, placed around the wrist to a pressure of $200 \mathrm{~mm} \mathrm{Hg}$. The venous occlusion cuff, placed around the upper arm, was automatically inflated (and deflated) to a pressure of $40 \mathrm{~mm} \mathrm{Hg}$. Forearm blood flow was recorded every $4 \mathrm{~s}$ (depending on heart rate) for $1.5 \mathrm{~min}$ and the consecutive (stable) values during the last minute were averaged. Because this method measured percent change in volume, the blood flow is related to $100 \mathrm{ml}$ of forearm tissue.

Skin blood flow. Preceding the measurements of total forearm blood flow, skin blood flow was determined by the laser Doppler technique (Periflux
PF3; Perimed Sweden) with an occluded hand circulation. The probe was placed on the ventral side of the forearm near the wrist joint. The laser Doppler method is a relative method in which the blood flow in the microcirculation can be expressed in qualitative terms [12]. For an estimation of quantitative skin blood flow it was assumed that resting skin blood flow was between 2.5 and $5 \mathrm{ml}$ $100 \mathrm{ml}^{-1} \mathrm{~min}^{-1}$ in both lean and obese subjects (see the Discussion section [13]).

Subcutaneous adipose tissue blood flow. Subcutaneous adipose tissue blood flow was measured on the dorsal side of the forearm about $10 \mathrm{~cm}$ proximal to the wrist joint by the ${ }^{133} \mathrm{Xe}$ washout method [8]. A dose of $5.5 \mathrm{MBq}(150 \mu \mathrm{Ci}){ }^{133} \mathrm{Xe}$, dissolved in saline, was injected subcutaneously with a very fine needle $(0.5 \times 16 \mathrm{~mm})$. The arm was placed in a fixed position close to a large field of view gamma camera (Technicare, large field 438 HR, General Electrics, Utrecht). The registration of ${ }^{1{ }^{33}} \mathrm{Xe}$ was started $45 \mathrm{~min}$ after the injection at which moment the washout is usually mono-exponential. From the regression of count rate against time, the disappearance constant of ${ }^{133} \mathrm{Xe}$ over the last 20 min of each measurement period was determined.

For the calculation of quantitative values of adipose tissue blood flow (per $100 \mathrm{ml}$ of tissue), the relative solubility of xenon in tissue and blood, i.e. the partition coefficient, must be known. The major determinants for the adipose tissue-blood partition coefficient are the lipid content of adipose tissue and the haematocrit value of the blood perfusing it. In the study of Martin et al. [14], the relationship between $\%$ adiposity and lipid fraction $(V)$ of adipose tissue was determined by means of underwater weighing of all portions of adipose tissue of human cadavers (range \% body fat 17.8 43.9) and was as follows:

$V=0.327+0.0124 x \%$ adiposity $(r=0.95, P<0.05)$

Given that the solubility of Xe in a tissue equals the weighted mean of the solubility in the individual tissue components [15], the following equations for the solubility of $\mathrm{Xe}$ in blood and adipose tissue can be given on the basis of data of Chen et al. [16]

$$
S_{\mathrm{B}}=H t S_{\mathrm{c}}+(1-\mathrm{Ht}) S_{\mathrm{P}}
$$

where $S_{\mathrm{B}}, S_{\mathrm{C}}, S_{\mathrm{P}}$ are solubility in blood, erythrocytes and plasma, respectively, and $\mathrm{Ht}$ is haematocrit.

Assuming that the solubility of $\mathrm{Xe}$ in water and protein within adipose tissue equals that of plasma yields the following equation:

$$
S_{\mathrm{A}}=V S_{\mathrm{L}}+(1-V) S_{\mathrm{P}}
$$

where $S_{\mathrm{A}}, S_{\mathrm{L}}, S_{\mathrm{P}}$ are solubility in adipose tissue, in lipid and in plasma, respectively, and $V$ is lipid fraction of adipose tissue. 
The tissue-blood partition coefficient of xenon for adipose tissue $(\lambda)$ can then be expressed as:

$$
\lambda=\frac{S_{\mathrm{A}}}{S_{\mathrm{B}}}=\frac{V\left(S_{\mathrm{L}} / S_{\mathrm{P}}-1\right)+1}{\mathrm{Ht}\left(S_{\mathrm{C}} / S_{\mathrm{P}}-1\right)+1}
$$

where $S_{\mathrm{P}}=0.0939 \mathrm{ml} / \mathrm{ml}, S_{\mathrm{L}}=1.8276 \mathrm{mg} / \mathrm{g}$ and $S_{\mathrm{C}}=$ $0.2710 \mathrm{ml} / \mathrm{ml}$.

On the basis of eqns (1) and (4), the tissue blood partition coefficient was calculated for each individual. For the conversion of blood flow values from $100 \mathrm{~g}$ to $100 \mathrm{ml}$ of fat tissue, the density of adipose tissue was assumed to be $0.9 \mathrm{~g} / \mathrm{ml}$ in both groups [10].

\section{Calculations and statistics}

A student's paired $t$-test was used for analysing within-group differences. Differences between lean and obese subjects were tested with an unpaired $t$ test. $P<0.05$ was regarded as statistically significant.

\section{RESULTS}

\section{Body composition}

The mean age, body mass index (BMI) and \% body fat were significantly lower in lean than obese subjects, as indicated in Table 1.

\section{Forearm composition}

Fig. 1 shows a magnetic resonance image depicting a cross section of the forearm at the site of the greatest circumference. The total forearm area was significantly higher in obese than lean subjects $(P<0.001$, Table 1). Lean subjects had less subcutaneous adipose tissue than obese subjects, when expressed as absolute values (lean vs obese: $773 \pm 51$ vs $\left.1629 \pm 97 \mathrm{~mm}^{2}, P<0.001\right)$ or as percentage of total forearm area (Table 1). As expected, there was a significant positive relationship between $\%$ total body fat and \% forearm adipose tissue $(r=0.82, P<0.001)$. The absolute amount of muscle was higher in obese than it was in lean subjects (lean vs obese: $3483 \pm 128$ vs $4849 \pm 313 \mathrm{~mm}^{2}$, $P<0.01$, but the relative amount was not significantly different. The amounts of skin and tendon were lower in lean than they were in obese subjects when expressed as absolute values (skin: $515 \pm 6$ vs $616 \pm 12 \mathrm{~mm}^{2}, \quad P<0.001$ and tendon $336 \pm 13$ vs $\left.449 \pm 29 \mathrm{~mm}^{2}, \quad P<0.01\right)$. When expressed as a percentage of the total forearm area the percentage tendon and skin were significantly lower in the obese subjects (Table 1). The absolute amount of bone did not differ between lean and obese subjects, but expressed as a relative figure this value was lower in the obese.
Table 2. Contribution of forearm subcutaneous adipose tissue blood flow to total forearm blood flow during rest and during the infusion of the $\beta$-agonist isoprenaline in lean and obese subjects. Values are means \pm SEM, lean, $n=8$; obese, $n=8$. Unpaired t-test: lean vs obese ${ }^{*} P=<0.05, t=P<0.01, t=P<0.001$. Student's paired t-test, ISO vs rest: $\S=P<0.05, \|=P<0.01$. Abbreviations: ATBF, adipose tissue blood flow; TBF, total forearm blood flow; ISO, isoprenaline.

\begin{tabular}{|c|c|c|}
\hline & Lean & Obese \\
\hline Haematocrit $(8)$ & $47.3 \pm 2.5$ & $47.1 \pm 1.2$ \\
\hline Lipid content adipose tissue $(\%)$ & $52 \pm 2$ & $71 \pm 2 \ddagger$ \\
\hline Partition coefficient (m//g) & $5.6 \pm 0.2$ & $7.2 \pm 0.2 \pm$ \\
\hline \multicolumn{3}{|c|}{ TBF $\left(\mathrm{ml} 100 \mathrm{~m}^{-1}\right.$ forearm tissue $\left.\mathrm{min}^{-1}\right)$} \\
\hline Rest & $1.43 \pm 0.13$ & $1.62 \pm 0.28$ \\
\hline 150 & $3.75 \pm 0.89 \|$ & $2.44 \pm 0.30 \|$ \\
\hline \multicolumn{3}{|c|}{ ATBF $\left(\mathrm{ml} 100 \mathrm{ml}^{-1}\right.$ adipose tissue $\left.\mathrm{min}^{-1}\right\rangle$} \\
\hline Rest & $1.80 \pm 0.24$ & $0.83 \pm 0.12 \uparrow$ \\
\hline ISO & $2.20 \pm 0.60$ & $1.38 \pm 0.30$ \\
\hline \multicolumn{3}{|c|}{$\begin{array}{l}\text { Contribution ATBF to TBF } \\
\left(\mathrm{ml} 100 \mathrm{ml}^{-1} \text { forearm tissue } \mathrm{min}^{-1}\right)\end{array}$} \\
\hline Rest & $0.25 \pm 0.03$ & $0.17 \pm 0.02 *$ \\
\hline ISO & $0.30 \pm 0.08$ & $0.29 \pm 0.06$ \\
\hline \multicolumn{3}{|l|}{$\%$ contribution ATBF to TBF } \\
\hline Rest & $18.8 \pm 2.6$ & $11.7 \pm 1.9 *$ \\
\hline ISO & $10.3 \pm 3.2 \S$ & $13.2 \pm 3.2$ \\
\hline
\end{tabular}

\section{Blood flow measurements}

Haematocrit values were similar in lean and obese men (Table 2). The calculated lipid content of adipose tissue was significantly higher in obese than in lean subjects and ranged in lean subjects from 40 to $62 \%$ and in obese subjects from 65 to $84 \%$. The mean value for the partition coefficient was calculated to be $5.6 \mathrm{ml} / \mathrm{g}$ in lean subjects (range 4.4-6.5) and $7.2 \mathrm{ml} / \mathrm{g}$ in obese subjects (range $6.6-8.3 \mathrm{ml} / \mathrm{g}$, Table 2).

There was a significant increase in absolute values of total forearm blood flow (TBF) as a result of infusion of ISO in both groups, and this increase was not significantly different between lean and obese subjects (lean: $+160 \%$, obese: $+50 \%$, Table 2). During rest, subcutaneous adipose tissue blood flow (ATBF) was significantly higher in lean than it was in obese subjects. In both groups ATBF was higher during ISO-infusion than it was during control periods but these changes did not reach statistical significance. The contribution of ATBF to TBF, calculated by multiplying the ATBF by the percentage of forearm adipose tissue $/ 100$, was significantly lower during rest in obese than it was in lean subjects, whereas during ISO there was no longer a statistically significant difference between both groups. Expressed as percentage of total blood flow there was a significantly higher contribution of adipose tissue blood flow to total blood flow in lean subjects during rest $(19 \%$, range $14-27 \%)$ as compared to obese subjects $(12 \%$, range $5-20 \%)$. During ISO the $\%$ contribution of adipose tissue blood flow to total blood flow was similar for both groups. The percentage contribution of ATBF to TBF was significantly lower during ISO infusion than it was 
during rest in lean subjects, whereas in the obese these values were similar.

The relative units for skin blood flow (SBF) were similar in lean and obese subjects (lean vs obese: $5.9 \pm 0.6$ vs $5.2 \pm 0.6$ units) and in both groups there were no changes as a result of ISO-infusion (lean vs obese ISO: $5.6 \pm 0.6$ vs $5.2 \pm 0.5$ units). Assuming a resting skin blood flow in lean and obese subjects in the range of 2.5 to $5 \mathrm{ml} 100 \mathrm{ml}^{-1} \mathrm{~min}^{-1}$ (see discussion), the contribution of skin and adipose tissue to total forearm blood flow can be estimated. The contribution of skin and adipose tissue to TBF are then estimated to be $35-50 \%$ during rest and $18-$ $25 \%$ during ISO in lean subjects, and $25-40 \%$ during rest and $23-33 \%$ during ISO in the obese subjects.

\section{DISCUSSION}

In the present study, the significance of forearm subcutaneous adipose tissue blood flow was evaluated in lean and obese subjects during rest and during infusion of the $\beta$-agonist isoprenaline. The data on the significance of subcutaneous adipose tissue blood flow are based on the following prerequisites:

(i) The individual values for the adipose tissueblood partition coefficient of xenon estimated on the basis of data of Martin et al. [14] and Chen et al. [16] are good estimations for the individual relative solubility of xenon between adipose tissue and blood. (ii) Total forearm blood flow can be measured with sufficient accuracy by means of strain gauge plethysmography. (iii) The total volume of muscle and subcutaneous adipose tissue can be differentiated with appropriate accuracy with magnetic resonance imaging.

\section{Tissue-blood partition coefficient}

For calculating absolute adipose tissue blood flow values from the washout curves of ${ }^{133}$ xenon, the tissue-blood partition coefficient must be known. The highest solubility coefficients for xenon are found for lipids and haemoglobin, which implies that the lipid content of adipose tissue and the haematocrit of the blood perfusing it will be the major determinants for the adipose tissue-blood partition coefficient $[16,17]$. In the present study, a correction was made for individual haematocrit values (see methods). Although the variation in lipid content of human subcutaneous adipose tissue reported by Martinsson et al. [18] would only slightly affect the partition coefficinet, Bülow et al. [19] reported a much higher variation in lipid content. In both studies, however, exact data on the percentage adiposity of the subjects are not given. The relationship between the $\%$ adiposity and the lipid content of total adipose tissue in the study of Martin et al. [14] has, as far as we are aware of, not previously been reported. Since subcutaneous adi- pose tissue comprises approximately two thirds of total adipose tissue [20], it may be assumed that the magnitude and the variation of the lipid content of total adipose tissue gives a reasonable representation of the lipid content in subcutaneous adipose tissue. Moreover, the range of the adipose tissue lipid fraction we found seems comparable to the range reported by Bülow et al. [19] for subcutaneous tissue on the abdomen and thigh. Our values for the tissue-blood partition coefficient are somewhat lower than values reported by Bülow et al. [19], which can be accounted for by higher haematocrit values and a lower average lipid content in our study as compared to the study of Bülow et al. [19].

For the conversion of blood flow values from $100 \mathrm{~g}$ to $100 \mathrm{ml}$ adipose tissue, the density of adipose tissue was assumed to be $0.9 \mathrm{~g} / \mathrm{ml}$ in both lean and obese subjects. However, the density of adipose tissue may be lower in obese as compared to lean subjects due to a higher lipid content of adipose tissue in the obese. An extreme difference in adipose tissue density between lean and obese subjects (all obese subjects: $0.9 \mathrm{~g} / \mathrm{ml}$, all lean subjects $1.0 \mathrm{~g} / \mathrm{ml}$ ) would, however, not significantly alter the results of this study.

\section{Strain gauge plethysmography}

A major criticism when measuring with strain gauge venous occlusion plethysmography is that the measured blood flow at a single limb segment may not be representative of total limb blood flow [21]. Comparisons of strain gauge plethysmography with other techniques showed slightly lower values with strain gauge plethysmography $[21,24,26]$, whereas a good agreement has also been reported $[1,25$, 26]. Thus, we cannot exclude that venous occlusion plethysmography underestimates total forearm blood flow. However, as indicated in a recent review [26] the values of forearm plethysmography are on average $15 \%$ lower than blood flow measurements obtained by other techniques. An underestimation of this magnitude would not change the major conclusions of this study. The resting total blood flow values measured in the present study are slightly lower than data from several other studies, obtained by means of strain gauge plethysmography [26]. This may be explained by a higher ambient temperature in those studies than in the present experiment $\left(21-23^{\circ} \mathrm{C}\right)$. The importance of ambient temperature was illustrated in a study of Frayn et al. [27], which reported much higher blood flow values at a temperature of $33^{\circ} \mathrm{C}$ rather than $23^{\circ} \mathrm{C}$, Indeed, our blood flow values are comparable to the values measured in the latter study at $23^{\circ} \mathrm{C}$ ambient temperature.

The measurement of total forearm blood flow occurred at the greatest forearm circumference. The ${ }^{133}$ xenon washout measurement occurred a little below the greatest forearm circumference, whereas 
skin blood flow was measured near the wrist joint. It was practically impossible to perform all measurements at exactly the same site. It has been reported that skin blood flow may vary between the different regions of human skin surface. For example, the perfusion has been reported to vary between fingers or ears and forearm skin [12]. It seems, however, most unlikely that large variations in the relative skin blood flow occur at sites of the forearm with about $10 \mathrm{~cm}$ in between.

\section{Tissue volumes}

The forearm composition was determined by means of three MRI slices at the site of the greatest forearm circumference. The determination of forearm composition was limited to volumes of subcutaneous adipose tissue, muscle and bone. By means of T1-weighted images, these tissue volumes could be easily differentiated, as previously reported [28]. Since it was hard to differentiate between muscle and tendonous structures, the relationship between the absolute amount of muscle and tendons was assumed to be constant, which seems justified due to their functional relationship. Furthermore, in our MRI-images it was not possible to obtain a clear image of the relatively thin human skin as found on the arm. Therefore, the relationship between the area of forearm skin and the total area of muscle and subcutaneous adipose tissue was assumed to be constant and was assumed to be as assessed with carcass analysis by Cooper et al. [2]

There was a significant correlation between percentage forearm adipose tissue (of total forearm area) and the \% total body fat as assessed by underwater weighing $(P<0.001)$, which indicates the MRI gives a reasonable estimation of the subcutaneous adipose tissue content, as reported before [28]. The amounts of forearm muscle and subcutaneous fat (in lean subjects) in our study seem comparable to data of computed tomography (CT) scanning at the greatest forearm circumference [23] or of the total forearm [29]. Furthermore, the area of bone is slightly lower than reported by CT scanning at the greatest forearm circumference [23] and considerably lower than the bone area reported for the total forearm [29]. The latter finding may be due a large variation in bone content between the proximal and distal part of the forearm [23].

\section{Contribution of forearm adipose tissue blood flow to total blood flow}

Resting forearm adipose tissue blood flow was significantly higher in lean than it was in obese subjects. Mean forearm adipose tissue blood flow values were higher during ISO infusion than they were during rest in both groups, but these increases did not reach statistical significance. In another study we have found that the ISO-induced increase in abdominal subcutaneous adipose tissue blood flow was much more pronounced in both lean and obese subjects (control vs ISO, lean 2.6 vs $10.6 \mathrm{ml}$ $100 \mathrm{~g}^{-1} \mathrm{~min}^{-1}, P<0.01$, and obese 1.0 vs $4.0 \mathrm{ml}$ $100 \mathrm{~g}^{-1} \mathrm{~min}^{-1}, P<0.01$; E. E. Blaak et al., unpublished work). This is in accordance with several other studies which reported a higher blood flow response in abdominal subcutaneous adipose tissue than in other subcutaneous depots after fasting [30], glucose ingestion [31] or catecholamine infusion [32].

On the basis of the findings in the present study, it can be concluded that the contribution of ATBF to TBF is relatively small and amounts on average to about $15 \%$. The mean value we calculated for the subcutaneous adipose-blood partition coefficient is lower than the previously reported partition coefficient of $8 \mathrm{ml} / \mathrm{g}$ [19]. Assuming an average partition coefficient of $8 \mathrm{ml} / \mathrm{g}$ would make the mean contribution of ATBF to TBF only slightly higher (18\%).

The contribution of ATBF to TBF was significantly higher in lean than it was in obese subjects (19 vs $12 \%$, respectively). Furthermore, the contribution of ATBF to TBF was significantly lower during ISO infusion than it was during rest in lean subjects ( 10 vs $18 \%$ ), whereas in the obese this value was similar during rest and during ISO infusion (in both situations 12-13\%). The above data indicate that although the overall contribution of ATBF to TBF is relatively small, this contribution may vary between groups with a varying degree of adiposity. In addition, the significantly lower $\%$ contribution of ATBF to TBF during ISO infusion compared to rest in lean subjects may indicate that in intervention studies where muscle blood flow is stimulated, the measurements of forearm blood flow in the intervention period may not be comparable to the baseline measurement. A factor that may have disturbed our data is the significant age difference between lean and obese subjects. However, Larsen and coworkers [8] reported no association between age and adipose tissue blood flow, which indicates that age was unlikely to be a confounding factor in the present study,

\section{Skin blood flow}

The circulation of skin is very sensitive to changes in environmental temperature. In our study ambient temperature was strictly controlled between 21$23^{\circ} \mathrm{C}$. Sejrsen et al. [13] reported a resting skin blood flow of $5 \mathrm{ml} 100 \mathrm{ml}^{-1} \mathrm{~min}^{-1}$ at a comparable ambient temperature as in the present study. Assuming a resting skin blood flow in the range of $2.5-5 \mathrm{ml} 100 \mathrm{ml}^{-1} \mathrm{~min}^{-1}$ would give a contribution of SBF plus ATBF to TBF ranging from $35-50 \%$. This calculation indicates that in normal weight volunteers nonmuscular blood flow may account for an important part of total blood flow in the resting 
state. Relative blood flow values, as assessed by laser Doppler flowmetry, were similar during rest and ISO-infusion, which indicates that as a result of ISO-infusion there were no large changes in skin blood flow. However, the laser Doppler method measures the flow in the skin capillary vessels and probably the flow in non-capillary vessels [34], which implies that changes in the diameter of the underlying subpapillary vessels may have biased the skin flow measurements. Since skin vessels mainly contain $\alpha$-adrenoceptors [35] a considerable change in contraction state of skin vessels as a result of ISO infusion (mainly $\beta$-adrenoceptor stimulation) [11] seems unlikely. In addition, an effect of other neural mechanisms on the contraction state of skin vessels at the end of a $30 \mathrm{~min}$ period of ISO-infusion seems unlikely since intravenous ISO-infusion (100 ng kg body weight ${ }^{-1} \mathrm{~min}^{-1}$ ) has been reported to cause a slight, transient vasodilatation of skin vessels which returned to resting values within $10 \mathrm{~min}$ after the initiation of the infusion [9]. When assuming a similar skin blood flow during rest and ISO infusion in lean men, it can be calculated that the relative contribution of ATBF plus SBF to TBF during ISO infusion is half of the contribution during rest. Moreover, even if there was a slight increase in SBF during ISO infusion (i.e. $2 \mathrm{ml} 100 \mathrm{ml}^{-1} \mathrm{~min}^{-1}$ ) that was not detected by the laser Doppler method, this would still give a considerably lower contribution of non-muscular blood llow to TBF during ISO compared to during rest (at a resting $S B F$ of $5 \mathrm{ml}$ $100 \mathrm{ml}^{-1} \mathrm{~min}^{-1+1}$ rest: $50 \%$, ISO: $30 \%$ ).

Since the values of skin blood flow (admittedly measured in relative units) were similar in lean and obese subjects, it seems reasonable to assume that there were no large differences in absolute resting skin blood flow between both groups. However, since we cannot exclude slight differences in resting blood flow due to differences in the contraction state of skin vessels at the present ambient temperature, it does not seem justified to compare the percentage contribution of ATBF plus SBF ot TBF in lean and obese subjects. Assuming no or only a slight difference in SBF during rest and ISO infusion in obese subjects (as suggested by the laser Doppler recordings), the contribution of SBF plus ATBF to TBF seems to be comparable in both conditions.

In conclusion, the overall contribution of ATBF to TBF seems to be relatively small, but this contribution may vary between groups with a varying degree of adiposity. The lower percentage contribution of ATBF to TBF during ISO infusion compared to during rest in lean males may indicate that in intervention studies where muscle blood flow is stimulated, the measurement of forearm blood flow in the intervention period may not be comparable to the baseline measurement. The above calculations on the contribution of SBF and ATBF to TBF indicate that the contribution of nonmuscular flow to TBF may be of considerable importance and may amount to $35-50 \%$ of TBF during rest in normal weight volunteers.

\section{REFERENCES}

1. Whitney RJ. The measurement of volume changes in human limbs. J Physiol (London) 1953; 121: 1-27.

2. Cooper KE, Edholm OG, Mottram RF. The blood flow in skin and muscle in human forearm. ) Physiol (London) 1955; 128: 258-67.

3. Edholm OG, Fox RH, Macpherson RK. The effect of body heating on the circulation in skin and muscle. J Physiol (London) 1956; 134; 612-9.

4. Kontos HA, Richardson DW, Patterson JL. Blood flow and metabolism of forearm muscle in man at rest and during sustained contraction. Am / Physiol (London) 1966; 211(4): 869-76.

5. Zelis R, Mason DT, Braunwald E. Partition of blood flow to the curaneaus and muscular beds of the forearm at rest and during leg exercise in normal subjects and in patients with heart failure. Circ Res 1969; XXIV; 799-806.

6. Bülow It Astrup A, Christensen NJ, Kastrup J. Blood now in skin, subcutaneous adipose tissue and skeletal muscle in the forearm of normal man during an oral glucose load. Acta Physiol Scand 1987; 130: 657-61.

7. Simonsen L, Bülow J, Astrup A, Madsen J, Christensen N), Diet-induced changes in subcutaneous adipose tissue blood flow in mant effect of $\beta$-adrenoceptor stimulation. Acta Physiol Scand 1990; 139; 34I-6.

8. Larsen OA, Lassen NA, Quaade F. Blood flow through human adjpose tissue determined with radioactive xenon. Acta Physiol Scand 1966; 66(3): 337-45.

9. Cobbald AF, Ginsburg ], Paton A. Circulatory, respiratory and metabolic responses to isopropylnoradrenaline in man. J Physiol (London) 1960; 151: 539-50.

10. Siri WE. The gross composition of the body, Adv Biol Med Physiol 1956; 4 : 239-80.

11. Blaak EE, van Baak MA, Kemerink G), Pakbiers MTW, Heidendal GAK, Sarls WHM. Effert of beta-adrenergic stimulation on energy expenditure and forearm skeletal muscle metabolism in lean and obese men. Am ] Physiol (Endocrinol Metab) (In press).

12. Oberg PA. Laser Doppler flowmetry. Biomed Eng 1990; 18(2): 125-63.

13. Sejrsen $P$. Blood flow in cutaneous tissue in man studied by washout of radioactive xenon. Circ Res 1969; 25: 215-29.

14. Martla AD, Drinkwater DT, Clarys JP. Adipose tissue density, estimated lipid fraction and whole body adiposity in male cadavars, Int / Obesity 1994; 18: $79-83$.

15. Yeh SY, Peterson RE. Solubility of krypton and xenon in blood, protein solutions, and tissue homogenates. J Appl Physiol 1965; 20(5): 1041-7.

16. Chen RY, Fan F, Kim S, Jan K, Usami S, Chien S. Tissue-blood partition coefficient for xenon: temperature and hematocrit dependence. J Appl Physiol 1980; 49: 178-83.

17. Bülow \}. Adipose tissue blood flow during exercise. Dan Med Bull 1983; 30: 85-100.

18. Martinsson A. On the composition of human adipose tissue. Acta Med Scand 1967; 82: 795-803.

19. Bülow J, Jelnes $R$, Astrup $A$, Madsen J, Vilmann P. Tissue/blood partition coefficlent for xenon in various adipose tissue depots in man. Scand / Lab Invest 1987; 47: $\{-3$.

20. Chien S, Peng MT, Chen KT, Huang TF, Chang C, Fang HS. Longitudina! studies on adipose tissue and its distribution in human subjects. I Appl Physiol 1975: 39: 825-30

21. Jorfeldt $L$, Rutberg $H$. Comparison of dye-dilution and plethysmographic blood flow measurements: an evaluation of the influence of invasive techniques on blood flow and on arterial and femoral venous substrate variables in man. Clin Sci 1990; 79; 81-7.

22. Reference deleted.

23. Weber $F$, Anlauf N, Serdarevic M. Noninvasive, quantitative determination of muscle blood flow by a combination of yenous-occlusion plethysmography and computed tomography, Basic Res Cardiol 1988; 83: 327-41.

24. Clark RSJ, Hellon RF. Venous collection in forearm and hand measured by strain gauge and volume plethysmography. Clin Sei 1957; 16: 103-17.

25. Hyman $C$, Winsor $T$. The application of the segmental plechysmography to the measurement of blood flow through the limbs of human beings. Am I Cardiol $1960 ; 6: 667-71$.

26. Williams $L R$, Legget $R W$. Reference values for resting blood flow to organs of man. Clin Phys Physiol Meas 1989; 10(3): |87-217.

27. Frayn KN, Whyte PL, Benson HA, Earl DJ, Smlth HA. Changes in forearm blood flow at elevated ambient temperature and their role in the apparent impairment of glucose tolerance. Clin Sci 1989; 76; 323-328. 